\title{
Polymorphism rs 3087243 is associated with the occurrence of ankylosing spondylitis in the West Algerian population
}

\author{
Type of article: Conference abstract \\ Chahinez Amira DAHMANI ${ }^{1}$, Ahmed BENZAOUI ${ }^{2}$, Fatima Zohra SEDIKI ${ }^{1}$, Leila ADDA \\ NEGGAZ ${ }^{1}$, Faouzia ZEMANI FODIL ${ }^{1}$, Elisabeth PETIT-TEIXEIRA ${ }^{3}$, Abdallah BOUDJEMA ${ }^{1}$ \\ 1. Laboratoire de Génétique Moléculaire et Cellulaire LGMC, Université des sciences et de \\ la technologie d'Oran Mohamed Boudiaf USTOMB
}

2. Service de Rheumatologie, Centre Hospitalo Universitaire d'Oran $\mathrm{CHU}$

3. Laboratoie Européen de recherche polyarthrite rhumatoide, GenHotel EA3886, Université d'Evry Val d'Essonne France

chahinez.dahmani@univ-usto.dz,chahinez.dahmani23@gmail.com

\begin{abstract}
Background: Numerous studies have shown that polymorphism rs231775 of the CTLA4 gene is strongly implicated in the development of ankylosing spondylitis (AS). Other polymorphisms of this gene are candidates that may have an additional effect in susceptibility to AS. For the first time, we searched for the association of rs3087243 polymorphism located in the 3'UTR region of the CTLA4 gene with the development of SA in the Algerian population.

Methods: The study involved 200 subjects (80 AS patients recruited at the rheumatology service and 120 healthy individuals unrelated). Genotyping was performed by real-time PCR $\left(\operatorname{Taqman}^{\circledR}\right)$. Analysis of the results was carried out by IBM.SPSS.Statictis ${ }^{\circledR}$ software.
\end{abstract}

Results: The distribution of allele frequencies showed a significant association between the GG genotype of the polymorphism rs3087243 and AS risk (OR=1.77 [0.98-3.21], $p=0.004)$.

Conclusion: Our data would suggest that the 3'UTR region of the CTLA4 gene could have an impact on the development of SA in the West Algerian population. These results need to be confirmed on a larger sample.

Keywords: rs3087243, CTLA4, Ankylosing Spondylitis, West of Algeria

\section{Declaration of conflicts}

This article was selected from the International Conference of Health Sciences and Medical Technologies 2016 ICHSMT'16 abstracts book. 


\section{Authors' biography}

No Biography

\section{References}

No reference 